Article

\title{
Evaluation of a Reduced Graphene Oxide-Sb Nanoparticles Electrochemical Sensor for the Detection of Cadmium and Lead in Chamomile Tea
}

\author{
Erik W. Nunes, Martin K. L. Silva ${ }^{\mathbb{D}}$ and Ivana Cesarino * $\mathbb{D}$ \\ Department of Bioprocesses and Biotechnology, School of Agriculture, São Paulo State University (UNESP), \\ Botucatu-18610-034, Brazil; erikwnunes@gmail.com (E.W.N.); martin.leme@unesp.br (M.K.L.S.) \\ * Correspondence: ivana.cesarino@unesp.br; Tel.: +55-14-3880-7404
}

Received: 16 June 2020; Accepted: 7 July 2020; Published: 10 July 2020

\begin{abstract}
The development of electroanalytical sensors for heavy metals detection in complex matrices holds great interest. Herein, a sensor based on a reduced graphene oxide (rGO) modified with antimony nanoparticles $(\mathrm{Sb})$ was developed for the electrochemical detection of divalent cadmium ions $\left(\mathrm{Cd}^{2+}\right)$ and lead ions $\left(\mathrm{Pb}^{2+}\right)$. The simultaneous determination of both metals covered a range of 0.1 to $3.0 \mu \mathrm{mol} \mathrm{L}{ }^{-1}$, with limits of detection (LOD) of 70.03 and $45.50 \mathrm{nmol} \mathrm{L}^{-1}$ for $\mathrm{Cd}^{2+}$ and $\mathrm{Pb}^{2+}$, respectively. For the individual detection, $\mathrm{LOD}$ of $20.50 \mathrm{nmol} \mathrm{L}^{-1}\left(\mathrm{Cd}^{2+}\right)$ and $2.01 \mathrm{nmol} \mathrm{L}^{-1}\left(\mathrm{~Pb}^{2+}\right)$ were found. The analytical performance of this new sensor in detecting both metals in chamomile tea samples was satisfactorily evaluated.
\end{abstract}

Keywords: graphene; tea; antimony nanoparticles; heavy metals; electroanalysis

\section{Introduction}

Heavy metals are well known for their relevance and extensive use in technological advances (or advancements). However, their wide distribution in the industrial, medical, agricultural, and food sectors raises the concern over the possibility of negative effects on the environment and human health [1]. Mainly in the agricultural sector, the irrigation of wastewater, vehicular exhaustion, prolong application of chemical fertilizers, and local industrial activities play a major role as the contamination route of the soil, revealing the direct or indirect influence of anthropogenic activities [2-4]. Several studies have already quoted the presence and influence of these contaminants, appointing to bioaccumulation as the major threat. This process is directly associated with the number of trophic levels between the origin of the food contamination and its final consumer, presenting a major problem for the agricultural production, thus affecting both quality and safety in consumption [5-7]. On the other side, the chronic intake of contaminated food, even in low doses, may induce neurologic, renal, osteoarticular disorders, besides leading to genetic and epigenetic dysfunctions, and associated as a risk factor for the development of some forms of cancer [8-10].

Being the second most consumed beverage worldwide, with its production reaching 5.8 million metric tons in 2018, tea is a possible route of contamination [11,12]. These data show its economic and cultural impact, enhancing the assurance of quality and safety in general tea production. Chamomile is one of the most popular herbal teas, most commonly represented by two varieties, Roman chamomile (Chamaemelum nobile) and German chamomile (Matricaria chamomilla) $[13,14]$. Its medical use dates back to ancient history, being one of the oldest medicinal herbs in our culture. The well documented medical properties as anti-inflammatory [15], antidiarrheal and antioxidant activities [16], potential management in type 2 diabetes [17], as well as its calming effects contributing for treatment of sleep disorders and anxiety $[13,18]$, are mainly associated to the variety of phenolic compounds (p. Ex. 
terpenoids) and rich content of essential oil (p. Ex. flavonoids) in its composition [19]. The preparation of commercially standardized tea and herbal extracts proceeds from dried flowers of the Matricaria species, and its main consumption is in the form of herbal tea $[13,14]$. However, as presented by Karak et al. [20], recent reports showed that the application of organic and inorganic fertilizers may boost the accumulation of heavy metals (HMs) in tea growing soils.

As an example, Vulcano et al. [21] detected the levels of cadmium and lead ions in chamomile and yerba mate tea (industrialized and non-industrialized samples) using atomic absorption spectrometry (AAS). In this report, both tea-infusion and digest plant samples were studied. Despite reporting HMs concentration values in chamomile samples below the safety limit, there was a considerably elevated concentration of $\mathrm{Cd}^{2+}$ in the digested yerba mate plant. Stipulated by the Brazilian Health Regulatory Agency (ANVISA), according to RDC 42/13, maximum limits for inorganic contaminants in stocks, for the categories tea, yerba mate, and other vegetables for infusion purposes, presents the limits for cadmium and lead as $0.4 \mathrm{mg} / \mathrm{kg}$ and $0.6 \mathrm{mg} / \mathrm{kg}$, respectively [22].

Therefore, several techniques for possible contaminants monitoring in tea samples have been proposed, having some of the methodologies shown by graphite furnace atomic absorption spectrometry (GF-AAS) [23], inductively coupled plasma mass spectroscopy (ICP-MS) [24] and laser-induced breakdown spectroscopy (LIBS) [25].

However, each technique presented has some disadvantages, such as sample preparation or the need for clean-up procedures prior to the experiment (due to the high content of interferents), the high cost of operation, or the impossibility of in situ analysis. In that way, electroanalytical techniques have been standing out in the last decade for offering an overall solution for those obstacles, in many works for environmental samples analysis, also offering fast and cheap analysis, with good selectivity [26].

One of the main aspects of developing a sensor on the electroanalytical field is choosing the material for the electrode's surface modification, which needs to provide good characteristics involving stability, electronic conductivity, surface area, and high sensibility [27]. Thus, since its discovery, graphene has shown itself as one of the most promising materials for several areas, such as electrochemistry, for presenting extraordinary electronic features [28,29]. Electrodes based on reduced graphene oxide (rGO) with the addition of metallic nanoparticles has shown as one of the most promising composites in the electroanalytical area due to the synergistic effect added to the excellent properties of rGO in the detection of environmental pollutants [30].

Cesarino et al. [31] developed a nanocomposite based on the synergistic combination of rGO with antimony nanoparticles (SbNPs) to perform detection of estriol hormones in environmental water samples; Zhang et al. [32] analyzed a nanocomposite of platinum nanoparticles combined with graphene oxide (PtNPs/GO) to be used as a signal transducer to develop an assay for the direct detection of cancer cells, showing a wide range of potential applications in biotechnology and medicine; and Silva et al. studied the stripping analysis of $\mathrm{Cd}^{2+}, \mathrm{Pb}^{2+}, \mathrm{Cu}^{2+}$, and $\mathrm{Hg}^{2+}$ in drinking water samples, using the nanocomposite based on the combination of rGO with SbNPs [33], demonstrating the benefits and potential of the synergistic effect gain with the addition of metallic nanoparticles.

In this way, this work presents the development of an electrochemical device based on rGO and $\mathrm{SbNPs}$ for the determination of lead $\left(\mathrm{Pb}^{2+}\right)$ and cadmium $\left(\mathrm{Cd}^{2+}\right)$ ions in chamomile tea-infusion samples.

\section{Materials and Methods}

\subsection{Reagents and Apparatus}

All reagents used in this study were of analytical grade and without prior purification. The graphene oxide $\left(4 \mathrm{mg} \mathrm{mL}^{-1}\right)$ and antimony chloride salt $\left(\mathrm{SbCl}_{3}\right)$ were purchased from Sigma-Aldrich (Darmstadt, Germany), as well as the standards solutions of $\mathrm{Cd}^{2+}$ and $\mathrm{Pb}^{2+}$ (standard AAS). Solutions and buffers were prepared using purified water in a PURELAB Option-Q-ELGA-VEOLIA (resistivity $\geq 18 \mathrm{M} \Omega \mathrm{cm}$ ). 
Cyclic voltammetry (CV) and square wave anodic stripping voltammetry (SWASV) experiments were performed using an electrochemical system model Autolab $128 \mathrm{~N}$ (Eco Chemie, Utrecht, The Netherlands) equipped with NOVA 2.1 software (Eco Chemie, Utrecht, The Netherlands). All electrochemical tests were conducted in a conventional three-electrode system with a bare glassy carbon electrode (GC), GC/GO, GC/rGO, or GC/rGO-SbNPs as the working electrode, $\mathrm{Ag} / \mathrm{AgCl} / \mathrm{KCl}$ $\left(3.0 \mathrm{~mol} \mathrm{~L}^{-1}\right)$ as the reference electrode, and a platinum plate as the auxiliary electrode.

\subsection{Synthesis of the Nanocomposites}

Initially, for the chemical reduction step, a suspension of GO and sodium dodecyl sulfate (SDS) was prepared in a 10:4 ratio in an ethanol medium, followed by a sonication step for $20 \mathrm{~min}$. Excess of sodium borohydride $\left(\mathrm{NaBH}_{4}\right)$ was then added $(16 \mathrm{mg})$ and a 20 min sonication was carried out. The solution was then centrifuged and cleaned several times with ethanol. The resulting rGO was dried at $60^{\circ} \mathrm{C}$ and dispersed in ultrapure water at a concentration of $1.0 \mathrm{mg} \mathrm{mL}^{-1}$. For optimization, the synthesis of the nanocomposite rGO-SbNPs was performed with four different antimony chloride $\left(\mathrm{SbCl}_{3}\right) / \mathrm{GO}$ ratios as follows: $20 \%, 30 \%, 40 \%$, and $50 \%$ of $\mathrm{SbCl}_{3}$.

The solution containing $\mathrm{SbCl}_{3}$ was added dropwise ( $\approx 1$ drop per second) to the rGO suspension under constant stirring. The product was then centrifuged for $10 \mathrm{~min}(3000 \mathrm{rpm})$ and washed four times with ethanol pure grade (the supernatant became colorless). The dried material was dispersed in ultrapure water $\left(0.3 \mathrm{mg} \mathrm{mL}^{-1}\right)$ and kept under refrigeration for further use. The rGO composite was synthesized as described above without the addition of the metallic salt. The materials were sonicated daily in order to prevent precipitation and to keep homogeneity of the film.

\subsection{Procedures}

The surface morphology was characterized by scanning electron microscopy (SEM) coupled to an electron gun (FEG-SEM), JEOL MODELO JSM7500F, at the Advanced Microscopy Laboratory (LMA) of the Institute of Chemistry-UNESP Araraquara. SEM micrographs were also obtained by Quanta 200 (FEI Company, Hillsboro, OR, USA) at the Electron Microscope Center of the Institute of Biosciences of Botucatu, UNESP.

For the electrochemical characterization of the composite, a CV experiment was conducted by comparing the GC/rGO and GC/rGO/SbNPs electrode's voltammetric profiles in $\mathrm{HCl} 0.5 \mathrm{~mol} \mathrm{~L}^{-1}$ solution, with a scan rate of $50 \mathrm{mV} \mathrm{s}^{-1}$ within the potential range of -0.6 to $+0.2 \mathrm{~V}$.

SWASV measurements were recorded in a $0.1 \mathrm{~mol} \mathrm{~L}^{-1} \mathrm{PBS}$ solution ( $\mathrm{pH} 3.0$ ), within a potential range of -1.0 to $-0.1 \mathrm{~V}$, with an accumulation potential of $-1.0 \mathrm{~V}$ for $120 \mathrm{~s}$, pulse amplitude of $90 \mathrm{mV}$ and $80 \mathrm{~Hz}$ frequency, containing $10.0 \mu \mathrm{mol} \mathrm{L}^{-1}$ of $\mathrm{Cd}^{2+}$ and $\mathrm{Pb}^{2+}$. These measurements were carried out at room temperature.

\subsection{Electrodes Preparation}

The glassy carbon electrodes (GC) were polished using $0.5 \mu \mathrm{m}$ alumina slurry. Then, the electrodes were sonicated for $5 \mathrm{~min}$ in ethanol and $5 \mathrm{~min}$ in ultrapure water and dried at room temperature. Finally, $10 \mu \mathrm{L}$ of the composites were dropped on the surfaces of the cleaned electrodes and dried at room temperature.

\subsection{Real Tea Samples}

A commercial tea bag of chamomile (acquired at a local market) containing $1 \mathrm{~g}$ of the sample was boiled within $50 \mathrm{~mL}$ ultrapure water and left to soak for $20 \mathrm{~min}$. The solution was transferred to a volumetric flask and nitric acid was added to achieve a $0.6 \%(v / v)$ solution [34]. The solution was kept under refrigeration prior to analysis. 


\section{Results and Discussion}

\subsection{Morphologic Characterization of Nanocomposites}

The surface morphology of rGO and rGO-SbNPs nanocomposites was characterized by scanning electron microscopy (FEG-SEM), as shown in Figure 1. The characteristic morphological structure of rGO is observed in Figure 1a. Its precursor, GO tends to form a mixture of single and multiple layers (sheets) as 2D material, the stacking of single sheets via electrons $\pi-\pi$ is commonly expected for this material. After the chemical reduction step, the rGO structure presents a distorted and wrinkled sheet of graphene due to unstacking. This process aims to decrease functional groups containing oxygen (mainly carbonyl and hydroxy), thus, making the material exhibit a typical twisted and wrinkled structure, which boosts its electronic properties for a more similar behavior of unmodified graphene.

Figure $1 b$ shows the integration of $\mathrm{Sb}$ nanoparticles on the rGO nanosheet surface. The morphologic analysis of this nanocomposite revealed nanoparticles with their size ranging from 50 to $150 \mathrm{~nm}$.

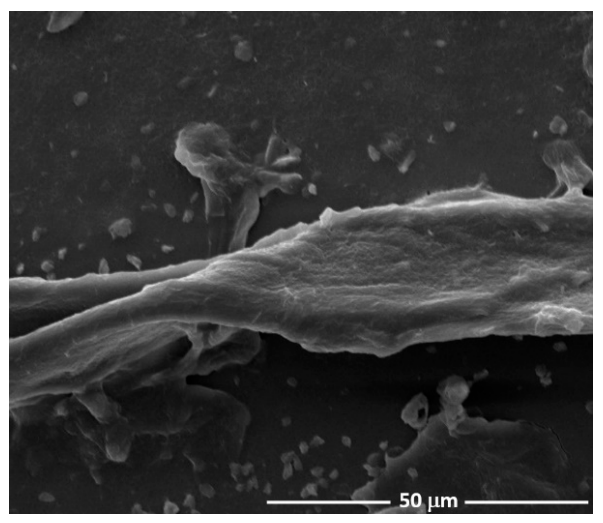

(a)

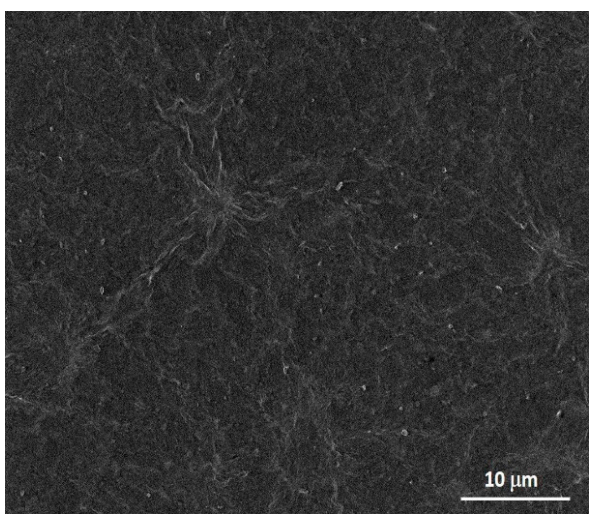

(b)

Figure 1. Scanning electron microscopy coupled to an electron gun (FEG-SEM) micrographs obtained for the nanocomposites (a) reduced graphene oxide (rGO) and (b) rGO with antimony nanoparticles (rGO-SbNPs).

\subsection{Electrochemical Characterization}

The electrochemical characterization of the GC/rGO-SbNPs electrode was evaluated using a CV experiment in a $0.5 \mathrm{~mol} \mathrm{~L}^{-1} \mathrm{HCl}$ solution. The voltammograms, shown in Figure 2, indicate the presence of $\mathrm{Sb}$ nanoparticles on the rGO surface (solid line). Two oxidation processes regarding SbNPs were observed at -16.5 and $100.7 \mathrm{mV}$. In the reverse scan, the GC/rGO-SbNPs electrode showed a reduction peak at $-331.4 \mathrm{mV}$. Both oxidation and reduction processes for $\mathrm{Sb}$ were already extensively observed in the literature [35,36]. In contrast, the GC/rGO electrode (dashed line) did not present any visible oxidation processes in the voltammetric profile.

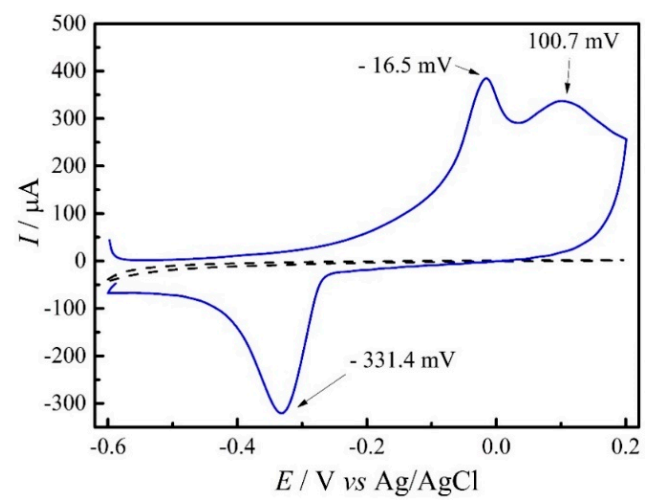

Figure 2. Cyclic voltammetry experiment of rGO (dashed line) and rGO-SbNPs (solid line) in a $0.5 \mathrm{~mol} \mathrm{~L}^{-1} \mathrm{HCl}$ solution. 


\subsection{Performance of GC/rGO-SbNPs Sensor for the Analysis of $\mathrm{Cd}^{2+}$ and $\mathrm{Pb}^{2+}$}

The stripping analysis for $10.0 \mu \mathrm{mol} \mathrm{L} \mathrm{L}^{-1}$ of $\mathrm{Cd}^{2+}$ and $\mathrm{Pb}^{2+}$ was conducted in a $0.1 \mathrm{~mol} \mathrm{~L}^{-1}$ PBS solution at pH 3.0, for the electrochemical comparison of the electrodes GC, GC/GO, GC/rGO, and GC/rGO-SbNPs.

As shown in Figure 3, the oxidation peaks for cadmium and lead ions are located near peak P1 at $E_{\mathrm{pa} 1}=-0.728 \mathrm{~V}\left(\mathrm{Cd}^{2+}\right)$ and peak P2 at $E_{\mathrm{pa} 2}=-0.481 \mathrm{~V}\left(\mathrm{~Pb}^{2+}\right)$ vs. $\mathrm{Ag} / \mathrm{AgCl} / \mathrm{KCl}\left(3.0 \mathrm{~mol} \mathrm{~L}^{-1}\right)$ for the four studied electrodes. The proposed electrode, GC/rGO-SbNPs (curve $\mathrm{d}$ ), presented the highest anodic peak currents for both metals when compared to the other studied electrodes, with an increase of approximately 2.4 times for the cadmium and 1.3 times for the lead ions response when compared to $\mathrm{GC} / \mathrm{rGO}$ electrode anodic peak current. This increase in the response signal for both metals is associated with the synergistic effect of rGO with SbNPs, appointing itself as a new material for the determination of $\mathrm{Cd}^{2+}$ and $\mathrm{Pb}^{2+}$ ions on tea samples.

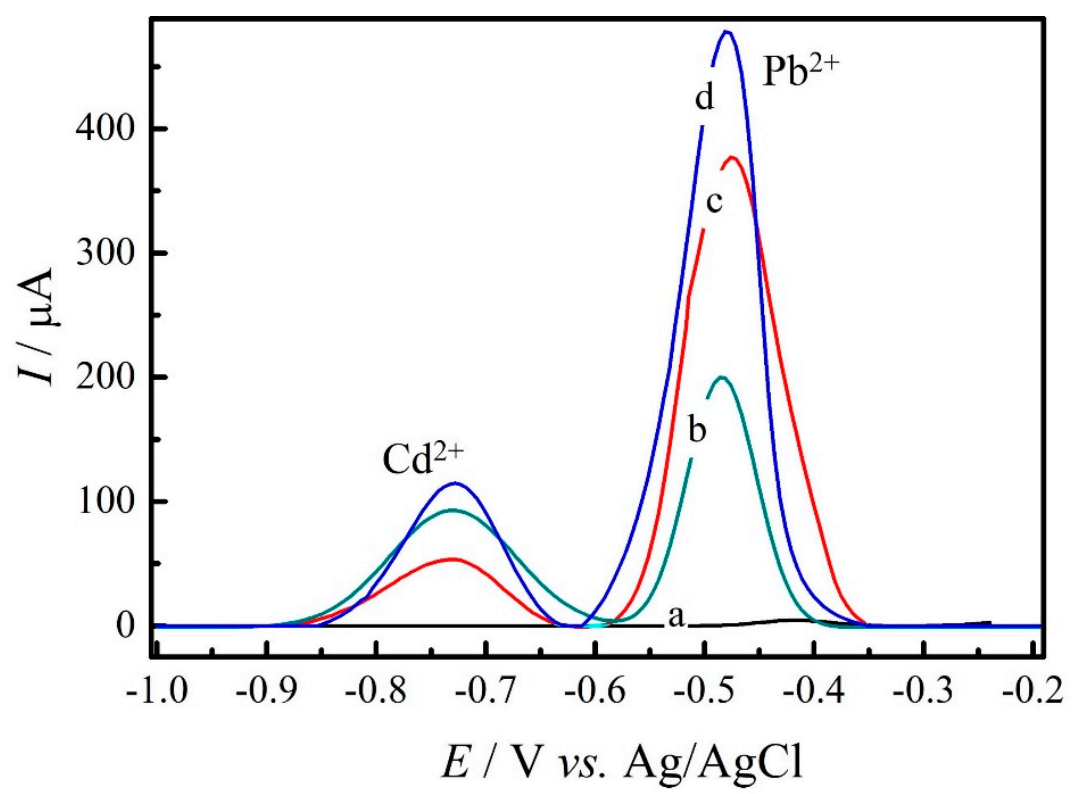

Figure 3. Square wave anodic stripping voltammetry (SWASV) data recorded in a PBS solution (0.1 mol L $\left.\mathrm{m}^{-1}, \mathrm{pH} 3.0\right)$ in the presence of $10.0 \mu \mathrm{mol} \mathrm{L}^{-1}$ of $\mathrm{Cd}^{2+}$ and $\mathrm{Pb}^{2+}$ for the electrodes: (a) GC, (b) GC/GO, (c) GC/rGO, and d) GC/rGO-SbNPs. Accumulation potential -1.0 V; accumulation time $120 \mathrm{~s}$; frequency of $80 \mathrm{~Hz}$ and pulse amplitude of $90 \mathrm{mV}$.

\subsection{Optimization of Experimental Parameters}

\subsubsection{Electrode Film Optimization}

In order to maximize the SWASV response, the parameters involving the nanocomposite synthesis were optimized. Thus, the influence of the $\mathrm{SbCl}_{3} / \mathrm{GO}$ ratio during synthesis was analyzed by varying the proportion for $20,30,40$, and $50 \%(\mathrm{~m} / \mathrm{m})$ compared to a fixed $20 \mathrm{mg}$ of GO. Thus, Figure 4 presents the highest anodic peak current $\left(I_{\mathrm{pa}}\right)$, for both metals, at a $30 \%$ nanocomposite ratio.

The film concentration of the modified electrode was also evaluated by SWASV experiments (figure not shown). The concentrations evaluated were 12.5, 25.0, 50.0, and $75.0 \mu \mathrm{g} \mathrm{mL}^{-1}$. The increase of the stripping peak current for both metals $\left(\mathrm{Cd}^{2+}\right.$ and $\left.\mathrm{Pb}^{2+}\right)$ was observed at $12.5 \mu \mathrm{g} \mathrm{mL} \mathrm{m}^{-1}$ of the film concentration, followed by a decrease in the electrode response when the composite concentration was raised. High concentrations of the nanocomposite may block the electron-transfer process through the electrode/electrolyte interface [37]. Therefore, the rGO-SbNPs (30\%) at $12.5 \mu \mathrm{g} \mathrm{mL}^{-1}$ was used in further experiments. 


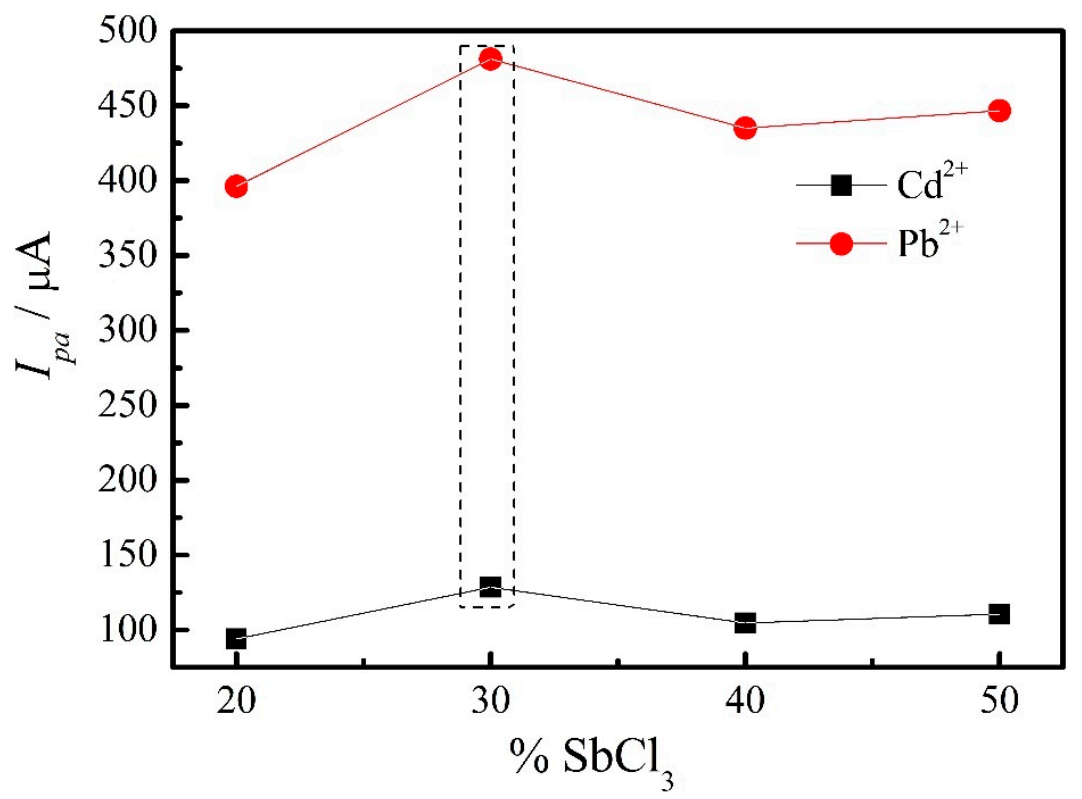

Figure 4. Effect of $\mathrm{SbCl}_{3}$ amount in the nanocomposite on the oxidation peak current of the $\mathrm{Cd}^{2+}$ and $\mathrm{Pb}^{2+}(\bullet)$.

\subsubsection{SWASV and Supporting Electrolyte Optimization}

A satisfactory performance of stripping analysis is directly linked with the parameters of the SWASV technique. As having a sensitive and linear response when detecting trace levels of heavy metals (as any possible contaminants), the optimization of SWASV parameters is required. The optimized SWASV parameters were frequency, pulse amplitude, accumulation time, and deposition potential at a fixed $10.0 \mu \mathrm{mol} \mathrm{L}^{-1}$ of $\mathrm{Cd}^{2+}$ and $\mathrm{Pb}^{2+}$ concentration in $0.1 \mathrm{~mol} \mathrm{~L}^{-1} \mathrm{PBS} \mathrm{pH}$ 3.0. Table 1 summarizes the range of the evaluated and optimized values found for each parameter.

Table 1. Optimized SWASV parameters for the simultaneous determination of cadmium and lead ions using the $\mathrm{GC} / \mathrm{rGO} / \mathrm{SbNPs}$ electrode.

\begin{tabular}{ccc}
\hline Parameter & Evaluated Range & Optimized Value \\
\hline Frequency & 10 to $90 \mathrm{~Hz}$ & $40 \mathrm{~Hz}$ \\
Pulse amplitude & 15 to $100 \mathrm{mV}$ & $100 \mathrm{mV}$ \\
Accumulation time & 45 to $150 \mathrm{~s}$ & $150 \mathrm{~s}$ \\
Deposition potential & -1.3 to $-0.8 \mathrm{~V}$ & $-1.2 \mathrm{~V}$ \\
pH of supporting electrolyte & 2.0 to 6.0 & 3.0 \\
\hline
\end{tabular}

Regarding the square wave voltammetry (SWV) detection, the frequency was optimized in the range of 10 to $90 \mathrm{~Hz}$, the pulse amplitude from 15 to $100 \mathrm{mV}$. The deposition potential was the first optimized anodic stripping parameter, ranging from -1.3 to $-0.8 \mathrm{~V}$, reaching the maximum response for both metals at $-1.2 \mathrm{~V}$. The second optimized anodic stripping parameter was the accumulation time, ranging from 45 to $150 \mathrm{~s}$, reaching the maximum response at $150 \mathrm{~s}$. The accumulation time increases the signal for heavy metals detection, due to a rise in the accumulation of metal ions on the electrode surface over time. However, it can be a time-consuming approach. As Wang et al. (2018) reported [38], after a 120-s accumulation time, the increase of the response was not so significant, due to the saturation of the enriched ions on the electrode surface. In this way, for the subsequent experiments, the accumulation time of $120 \mathrm{~s}$ at $-1.2 \mathrm{~V}$ was employed.

The $\mathrm{pH}$ variation during stripping analysis plays an important role in the detection of heavy metals [23], as high $\mathrm{pH}$ values may cause the precipitation of metals in its oxide form [39]. Therefore, 
the $\mathrm{pH}$ of the PBS buffer was investigated for both metals in the range of 2.0 to 6.0 , with its maximum response at $\mathrm{pH} 3.0$.

\subsection{Calibration Curves}

The calibration curves for $\mathrm{Cd}^{2+}$ and $\mathrm{Pb}^{2+}$ were built in two different experiments under optimized conditions as described earlier. In the first one, both metals were detected simultaneously in the range of 0.1 to $3.0 \mu \mathrm{mol} \mathrm{L}^{-1}$, as shown in Figure 5a. Despite the higher response for $\mathrm{Pb}^{2+}$, both metals presented a linear response of the anodic peak current vs. metal concentration, as shown in Figure $5 \mathrm{~b}$.

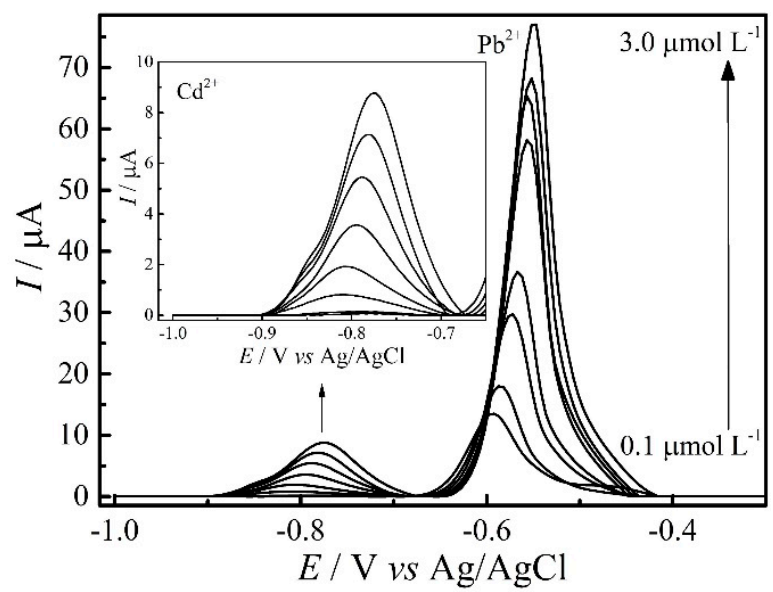

(a)

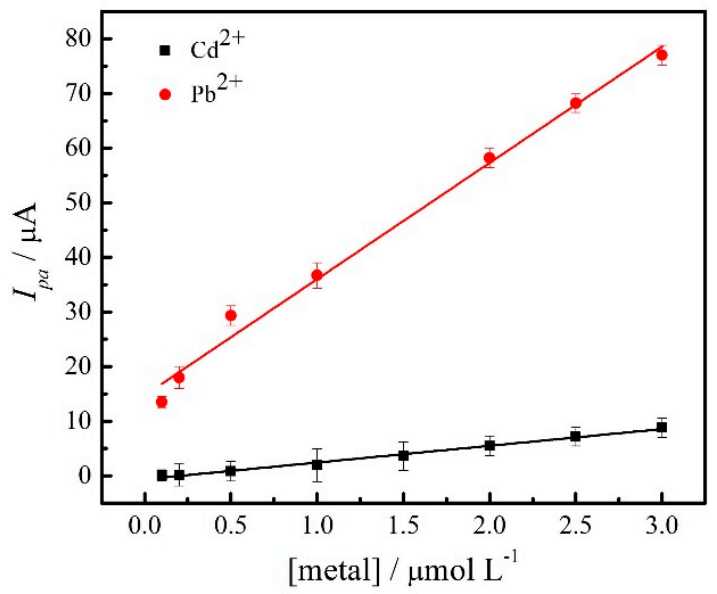

(b)

Figure 5. Simultaneous determination of both metals. (a) SWASV profiles recorded in a $0.1 \mathrm{~mol} \mathrm{~L}^{-1}$ PBS (pH 3.0) solution; (b) linear regression for $\mathrm{Cd}^{2+}(\boldsymbol{\square})$ and $\mathrm{Pb}^{2+}(\bullet)$ from 0.1 to $3.0 \mu \mathrm{mol} \mathrm{L}-1$.

The second experiment consisted of building both calibration curves individually, as shown in Figure 6. The response $\mathrm{Cd}^{2+}$ ions were obtained in the range of 50 to $120 \mathrm{nmol} \mathrm{L}^{-1}$ (Figure 6a) and $\mathrm{Pb}^{2+}$ within the range of 5 to $60 \mathrm{nmol} \mathrm{L}^{-1}$ (Figure $6 \mathrm{~b}$ ).

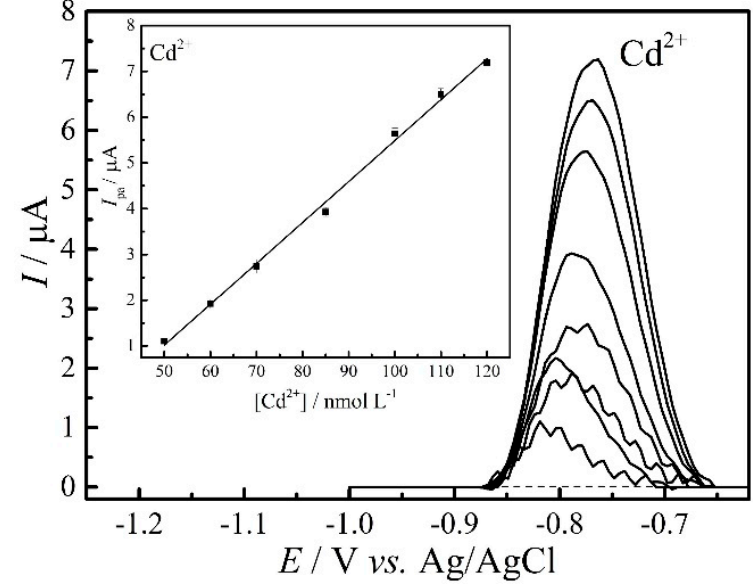

(a)

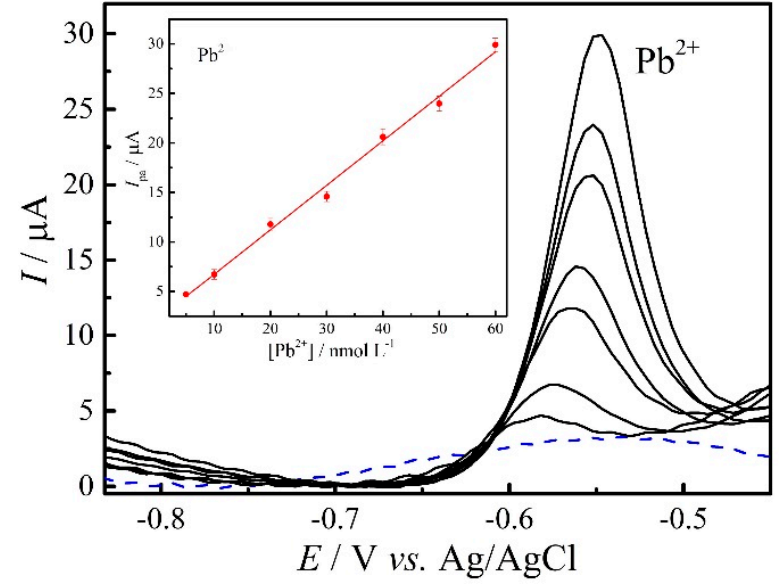

(b)

Figure 6. Individual determination by SWASV for (a) $\mathrm{Cd}^{2+}$ in the range of 50 to $120 \mathrm{nmol} \mathrm{L}^{-1}$; (b) $\mathrm{Pb}^{2+}$ in the range of 5 to $60 \mathrm{nmol} \mathrm{L}^{-1}$. SWASV parameters were the same used for the simultaneous curves.

Table 2 summarizes the method of detection (simultaneous/individual), equation of calibration curve, linear range, linearity $\left(\mathrm{R}^{2}\right)$, and obtained LOD in $\mathrm{nmol} \mathrm{L}^{-1}$ of the experiments described above. 
Table 2. Method of determination, equation of calibration curve, linear range, linearity and determined limits of detection (LOD) for the SWASV experiments.

\begin{tabular}{|c|c|c|c|c|c|}
\hline Metals & Method & Calibration Curve & Linear Range & $\mathbf{R}^{2}$ & LOD (nmol L $\left.{ }^{-1}\right)$ \\
\hline \multirow[t]{2}{*}{$\mathrm{Cd}^{2+}$} & Simultaneous & $I_{\mathrm{pa}}=0.64+3.06 \mathrm{C}_{\mathrm{Cd}^{2+}}$ & $0.1-3.0 \mu \mathrm{mol} \mathrm{L}{ }^{-1}$ & 0.9901 & 70.03 \\
\hline & Individual & $I_{\mathrm{pa}}=3.45+0.09 \mathrm{C}_{\mathrm{Cd}^{2+}}$ & $50-120 \mathrm{nmol} \mathrm{L}^{-1}$ & 0.9963 & 20.50 \\
\hline \multirow[t]{2}{*}{$\mathrm{Pb}^{2+}$} & Simultaneous & $I_{\mathrm{pa}}=14.70+21.30 \mathrm{C}_{\mathrm{Pb}}{ }^{2+}$ & $0.1-3.0 \mu \mathrm{mol} \mathrm{L}{ }^{-1}$ & 0.9898 & 45.50 \\
\hline & Individual & $I_{\mathrm{pa}}=2.24+0.45 \mathrm{C}_{\mathrm{Pb}}{ }^{2+}$ & $5-60 \mathrm{nmol} \mathrm{L}^{-1}$ & 0.9932 & 2.01 \\
\hline
\end{tabular}

The development of electrochemical sensors based on rGO and metallic nanoparticles for selective detection of $\mathrm{Cd}^{2+}$ and $\mathrm{Pb}^{2+}$ have been widely investigated. Wu et al. [40] developed an aluminum-silicon carbide-rGO nanocomposite electrode with LODs down to $19.13 \mathrm{nmol} \mathrm{L}^{-1}$ for $\mathrm{Cd}^{2+}$ and $6.27 \mathrm{nmol} \mathrm{L}^{-1}$ for $\mathrm{Pb}^{2+}$.

Lee et al. [41] developed a similar model compared to the presented study. A rGO modified with Sn nanoparticles-based electrode achieved LODs of $0.63 \mathrm{nmol} \mathrm{L}^{-1}$ for $\mathrm{Cd}^{2+}$ and $0.60 \mathrm{nmol} \mathrm{L}^{-1}$ for $\mathrm{Pb}^{2+}$.

Sang et al. [42] tested the sensor based on rGO modified with AgNPs. Through SWASV experiments, the developed sensor exhibited excellent electrochemical activity and sensitivity towards the detection of several heavy metal ions, as $\mathrm{Cd}^{2+}$ and $\mathrm{Pb}^{2+}$ LODs of 254.0 and $141.0 \mathrm{nmol} \mathrm{L}^{-1}$, respectively.

Liu et al. [43] modified the GC electrode with liquid phase exfoliated graphene nanosheets, prepared through a one-step exfoliation. The developed sensors showed increased response for the electrochemical signals for $\mathrm{Cd}^{2+}$ and $\mathrm{Pb}^{2+}$, with noteworthy signal amplification effects. The LODs determined by this sensor were $11.60 \mathrm{nmol} \mathrm{L}^{-1}$ for $\mathrm{Cd}^{2+}$ and $8.93 \mathrm{nmol} \mathrm{L}^{-1}$ for $\mathrm{Pb}^{2+}$.

The GC/rGO-SbNPs sensor developed in this work has similar LODs for $\mathrm{Cd}^{2+}$ and $\mathrm{Pb}^{2+}$ as reported in the literature. Although there are many important types of research in the development of new electroanalytical sensors towards heavy metal detection, the practical application of such sensors is required. In that way, this study evaluated the selective determination of the metals in question in infused chamomile tea samples.

The reproducibility of the GC/rGO-SbNPs electrode was also investigated. For this study, five experiments were measured, in which each experiment consisted of ten sequential SWASV voltammograms. These experiments were performed on different days, in which the electrodes were prepared day-to-day, in other words, using different films. The SWASV voltammograms were performed under the optimized conditions containing $0.5 \mu \mathrm{mol} \mathrm{L}^{-1} \mathrm{of} \mathrm{Cd}^{2+}$ and $\mathrm{Pb}^{2+}$. The calculated standard deviations were $2.8 \%$ and $1.9 \%$ for $\mathrm{Cd}^{2+}$ and $\mathrm{Pb}^{2+}$, respectively.

\subsection{Interference Study}

In aromatic beverages, such as chamomile tea, some common interferents may be present. Thus, the recovery signal of the voltammetric response for $\mathrm{Cd}^{2+}$ and $\mathrm{Pb}^{2+}$ was tested in the absence and the presence of $1.0 \mu \mathrm{mol} \mathrm{L}-1$ of some common interferents.

Caffeine, an alkaloid, is one of the most common components in tea [44]; as the proposed analytical method does not incinerate/destroy the organic molecules in the matrix, its effect on the metal signal was evaluated. The interfering caffeine did not shift drastically and influence the response for both metals, holding a deviation of $\pm 10 \%$ from the original signal.

The matrix evaluated was prepared using drinking water, which may contain $\mathrm{Hg}^{2+}$ and $\mathrm{Cu}^{2+}$ ions [45]. When tested, however, both ions had similar behavior as caffeine and did not influence significantly the signal of $\mathrm{Cd}^{2+}$ and $\mathrm{Pb}^{2+}$.

Although $\mathrm{Ag}^{2+}$ ions are not a common inorganic contaminant in tea samples, it has an incisive influence on the oxidation processes for both metals, exceeding $\pm 20 \%$ from the original signal. The results are presented in Figure 7. 


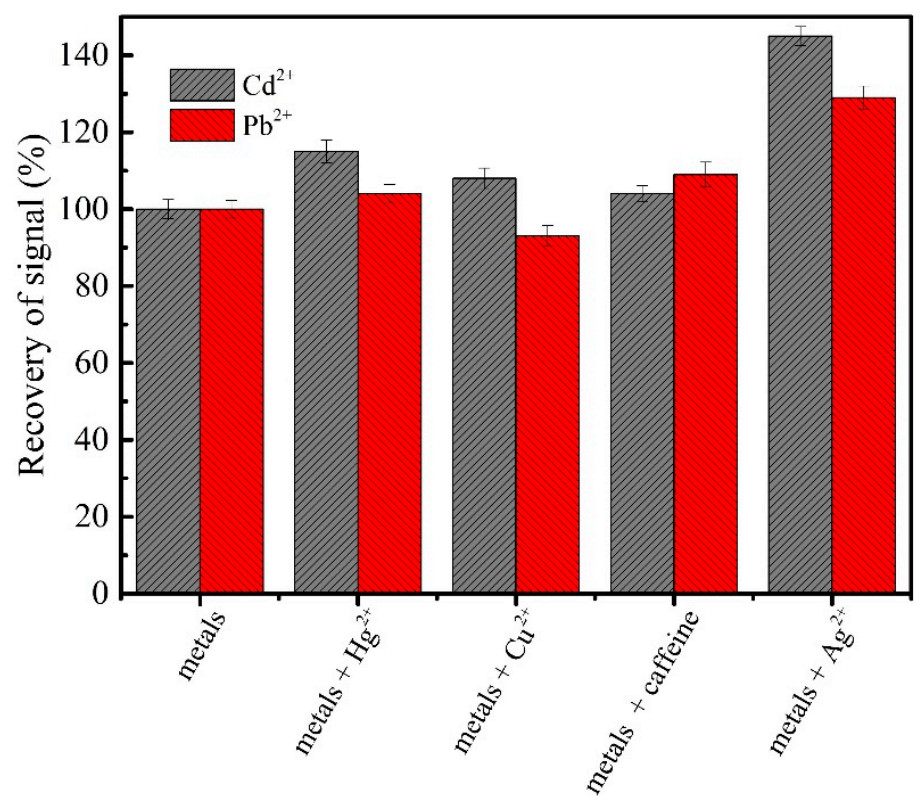

Figure 7. Recovery of $\mathrm{Cd}^{2+}$ and $\mathrm{Pb}^{2+}\left(0.5 \mu \mathrm{mol} \mathrm{L}{ }^{-1}\right)$ signals in the absence and the presence of $1.0 \mu \mathrm{mol} \mathrm{L}-1$ of common interferents.

\subsection{Real Samples Analysis}

Table 3 summarizes the results for the detection of $\mathrm{Cd}^{2+}$ and $\mathrm{Pb}^{2+}$ in the chamomile tea sample (infusion). For the detection of both metals, $5 \mathrm{~mL}$ of the previously prepared tea was diluted in $15 \mathrm{~mL}$ of PBS (pH 3.0), this solution was enriched with $0.5 \mu \mathrm{mol} \mathrm{L}^{-1}$ of both metals. The determination was conducted using the standard addition method by spiking the sample with metal standards.

Table 3. Results for the determination of $\mathrm{Cd}^{2+}$ and $\mathrm{Pb}^{2+}$ unfused sample of chamomile tea by SWASV proposed.

\begin{tabular}{cccc}
\hline Metals & Added $\left(\mu \mathbf{m o l ~ L}^{-\mathbf{1}}\right)$ & Recovery $\left(\mu \mathbf{m o l ~ L}^{-\mathbf{1}}\right)$ & Error $(\%)^{\mathbf{1}}$ \\
\hline $\mathrm{Cd}^{2+}$ & 0.5 & 0.4874 & -2.6 \\
& & 0.5376 & 7.0 \\
& & 0.5152 & 3.0 \\
& Mean $\pm \mathrm{SD}$ & $0.5134 \pm 0.0250$ & \\
$\mathrm{~Pb}^{2+}$ & & 0.5159 & 3.1 \\
& 0.5 & 0.4976 & -0.5 \\
& & 0.5085 & 1.7 \\
\hline
\end{tabular}

\footnotetext{
${ }^{1}$ Error: SWASV vs. added (SWASV-added/added) $\times 100 \%$.
}

According to the results, there was not a significant difference between the added and found concentrations of $\mathrm{Cd}^{2+}$ and $\mathrm{Pb}^{2+}$, the relative errors within $\pm 10 \%$ range. Based on these results, the proposed GC/rGO-SbNPs could be used for the selective detection of the metals in tea samples.

\section{Conclusions}

In this study, an rGO-SbNPs nanocomposite was designed and tested in the selective detection of $\mathrm{Cd}^{2+}$ and $\mathrm{Pb}^{2+}$. Both individual and simultaneous determination of heavy metal ions were investigated. The proposed sensor showed good limits of detection compared to similar methodologies reported in the literature. Furthermore, the GC/rGO-SbNPs electrode presented a practical application on the detection of heavy metal ions in a complex matrix, such as chamomile tea. The SWASV experiments did not reveal significant influence on the signals of $\mathrm{Cd}^{2+}$ and $\mathrm{Pb}^{2+}$, for a range of organic and inorganic 
interferents. Therefore, the developed work fills a gap in the development of electroanalytical devices towards metals detection in complex matrices.

Author Contributions: Conceptualization, I.C.; Data curation, M.K.L.S.; Formal analysis, E.W.N. and M.K.L.S.; Funding acquisition, I.C.; Investigation, E.W.N. and M.K.L.S.; Methodology, M.K.L.S.; Project administration, I.C.; Resources, I.C.; Supervision, I.C.; Writing—original draft, E.W.N. and M.K.L.S.; Writing-review \& editing, I.C. All authors have read and agreed to the published version of the manuscript.

Funding: This research received funding from Fapesp process (2018/09053-3) and the APC was funded by Fapesp process (2017/24274-3).

Conflicts of Interest: The authors declare no conflicts of interests.

\section{References}

1. Tchounwou, P.B.; Yedjou, C.G.; Patlolla, A.K.; Sutton, D.J. Heavy metal toxicity and the environment. Exp. Suppl. 2012, 101, 133-164.

2. Chen, Y.; Wang, C.; Wang, Z. Residues and source identification of persistent organic pollutants in farmland soils irrigated by effluents from biological treatment plants. Environ. Int. 2005, 31, 778-783. [CrossRef] [PubMed]

3. Kachenko, A.G.; Singh, B. Heavy metals contamination in vegetables grown in urban and metal smelter contaminated sites in Australia. Water Air Soil Pollut. 2006, 169, 101-123. [CrossRef]

4. Alloway, B.J. Sources of Heavy Metals and Metalloids in Soils. In Heavy Metals in Soils; Springer: Amsterdam, The Netherlands, 2013; pp. 11-50.

5. Rattan, R.K.; Datta, S.P.; Chhonkar, P.K.; Suribabu, K.; Singh, A.K. Long-term impact of irrigation with sewage effluents on heavy metal content in soils, crops and groundwater-A case study. Agric. Ecosyst. Environ. 2005, 109, 310-322. [CrossRef]

6. Morel, F.M.M.; Kraepiel, A.M.L.; Amyot, M. The chemical cycle and bioaccumulation of mercury. Annu. Rev. Ecol. Syst. 1998, 29, 543-566. [CrossRef]

7. Volesky, B.; Holan, Z.R. Biosorption of Heavy Metals. Biotechnol. Prog. 1995, 11, 235-250. [CrossRef] [PubMed]

8. Bower, J.J.; Leonard, S.S.; Shi, X. Conference overview: Molecular mechanisms of metal toxicity and carcinogenesis. Mol. Cell. Biochem. 2005, 279, 3-15. [CrossRef]

9. Järup, L. Hazards of heavy metal contamination. Br. Med. Bull. 2003, 68, 167-182. [CrossRef]

10. Zhou, S.; Luoma, S.E.; St. Armour, G.E.; Thakkar, E.; Mackay, T.F.C.; Anholt, R.R.H. A drosophila model for toxicogenomics: Genetic variation in susceptibility to heavy metal exposure. PLoS Genet. 2017, 13, e1006907. [CrossRef]

11. Shahbandeh, M. Tea Production and Exports Worldwide, 2018|Statista. Available online: https://www.statista. com/statistics/264183/global-production-and-exports-of-tea-since-2004/ (accessed on 26 June 2020).

12. Bennetzen, J. Culturing better tea research. Nature 2019, 566, S5. [CrossRef]

13. Srivastava, J.K.; Shankar, E.; Gupta, S. Chamomile: A herbal medicine of the past with a bright future (review). Mol. Med. Rep. 2010, 3, 895-901. [PubMed]

14. McKay, D.L.; Blumberg, J.B. A review of the bioactivity and potential health benefits of chamomile tea (Matricaria recutita L.). Phyther. Res. 2006, 20, 519-530. [CrossRef] [PubMed]

15. Kim, H.J.; Lee, W.; Yun, J.M. Luteolin Inhibits hyperglycemia-induced proinflammatory cytokine production and its epigenetic mechanism in human monocytes. Phyther. Res. 2014, 28, 1383-1391. [CrossRef] [PubMed]

16. Sebai, H.; Jabri, M.A.; Souli, A.; Rtibi, K.; Selmi, S.; Tebourbi, O.; El-Benna, J.; Sakly, M. Antidiarrheal and antioxidant activities of chamomile (Matricaria recutita L.) decoction extract in rats. J. Ethnopharmacol. 2014, 152, 327-332. [CrossRef] [PubMed]

17. Saeed Khan, S.; Najam, R.; Anser, H.; Riaz, B.; Alam, N. Chamomile tea: Herbal hypoglycemic alternative for conventional medicine. Pak. J. Pharm. Sci. 2014, 27, 1509-1514.

18. Chaves, P.F.P.; Iacomini, M.; Cordeiro, L.M.C. Chemical characterization of fructooligosaccharides, inulin and structurally diverse polysaccharides from chamomile tea. Carbohydr. Polym. 2019, 214, 269-275. [CrossRef]

19. Nováková, L.; Vildová, A.; Mateus, J.P.; Gonalves, T.; Solich, P. Development and application of UHPLC-MS/MS method for the determination of phenolic compounds in Chamomile flowers and Chamomile tea extracts. Talanta 2010, 82, 1271-1280. [CrossRef] 
20. Karak, T.; Bora, K.; Paul, R.K.K.; Das, S.; Khare, P.; Dutta, A.K.K.; Boruah, R.K.K. Paradigm shift of contamination risk of six heavy metals in tea (Camellia sinensis L.) growing soil: A new approach influenced by inorganic and organic amendments. J. Hazard. Mater. 2017, 338, 250-264. [CrossRef]

21. Vulcano, I.R.C.; Silveira, J.N.; Alvarez-Leite, E.M. Teores de chumbo e cádmio em chás comercializados na região metropolitana de Belo Horizonte. Rev. Bras. Ciências Farm. 2008, 44, 425-431. [CrossRef]

22. Brasil Ministério da Saúde Agência Nacional de Vigilância Sanitária; RDC 42/2013. Available online: http: //bvsms.saude.gov.br/bvs/saudelegis/anvisa/2013/rdc0042_29_08_2013.html (accessed on 9 July 2020).

23. Rashid, M.H.; Fardous, Z.; Chowdhury, M.A.Z.; Alam, M.K.; Bari, M.L.; Moniruzzaman, M.; Gan, S.H. Determination of heavy metals in the soils of tea plantations and in fresh and processed tea leaves: An evaluation of six digestion methods. Chem. Cent. J. 2016, 10, 7. [CrossRef]

24. Li, L.; Fu, Q.L.; Achal, V.; Liu, Y. A comparison of the potential health risk of aluminum and heavy metals in tea leaves and tea infusion of commercially available green tea in Jiangxi, China. Environ. Monit. Assess. 2015, 187, 228. [CrossRef] [PubMed]

25. Wang, J.; Shi, M.; Zheng, P.; Xue, S. Quantitative Analysis of Lead in Tea Samples by Laser-Induced Breakdown Spectroscopy. J. Appl. Spectrosc. 2017, 84, 188-193. [CrossRef]

26. Lu, Y.; Liang, X.; Niyungeko, C.; Zhou, J.; Xu, J.; Tian, G.; Yuanyuan, L.; Xinqiang, L.; Niyungeko, C.; Junjie, Z.; et al. A review of the identification and detection of heavy metal ions in the environment by voltammetry. Talanta 2017, 178, 324-338. [CrossRef] [PubMed]

27. Wang, J. Analytical Electrochemistry; John Wiley \& Sons Inc.: Hoboken, NJ, USA, 2000; p. 232, ISBN 0471282723.

28. Wallace, P.R. The band theory of graphite. Phys. Rev. 1947, 71, 622-634. [CrossRef]

29. Dreyer, D.R.; Ruoff, R.S.; Bielawski, C.W. From conception to realization: An historial account of graphene and some perspectives for its future. Angew. Chem. Int. Ed. 2010, 49, 9336-9344. [CrossRef]

30. Huang, K.J.; Niu, D.J.; Liu, X.; Wu, Z.W.; Fan, Y.; Chang, Y.F.; Wu, Y.Y. Direct electrochemistry of catalase at amine-functionalized graphene/gold nanoparticles composite film for hydrogen peroxide sensor. Electrochim. Acta 2011, 56, 2947-2953. [CrossRef]

31. Cesarino, I.; Cincotto, F.H.; Machado, S.A.S. A synergistic combination of reduced graphene oxide and antimony nanoparticles for estriol hormone detection. Sens. Actuators B Chem. 2015, 210, 453-459. [CrossRef]

32. Zhang, L.N.; Deng, H.H.; Lin, F.L.; Xu, X.W.; Weng, S.H.; Liu, A.L.; Lin, X.H.; Xia, X.H.; Chen, W. In situ growth of porous platinum nanoparticles on graphene oxide for colorimetric detection of cancer cells. Anal. Chem. 2014, 86, 2711-2718. [CrossRef]

33. Silva, M.K.L.; Cesarino, I. Electrochemical sensor based on Sb nanoparticles/reduced graphene oxide for heavy metal determination. Int. J. Environ. Anal. Chem. 2020,1-15. [CrossRef]

34. Anderson, K. Analytical Techniques for Inorganic Contaminants; AOAC International: Rockville, MD, USA; Gaithersburg, MD, USA, 1999; p. 193, ISBN 9780935584653.

35. Hocevar, S.B.; Švancara, I.; Ogorevc, B.; Vytřas, K. Antimony film electrode for electrochemical stripping analysis. Anal. Chem. 2007, 79, 8639-8643. [CrossRef]

36. Moraes, F.C.; Cesarino, I.; Cesarino, V.; Mascaro, L.H.; MacHado, S.A.S. Carbon nanotubes modified with antimony nanoparticles: A novel material for electrochemical sensing. Electrochim. Acta 2012, 85, 560-565. [CrossRef]

37. da Silva, M.K.L.; Vanzela, H.C.; Defavari, L.M.; Cesarino, I. Determination of carbamate pesticide in food using a biosensor based on reduced graphene oxide and acetylcholinesterase enzyme. Sens. Actuators B Chem. 2018, 277, 555-561. [CrossRef]

38. Wang, X.; Sun, J.; Tong, J.; Guan, X.; Bian, C.; Xia, S. Paper-based sensor chip for heavy metal ion detection by SWSV. Micromachines 2018, 9, 150. [CrossRef] [PubMed]

39. Cesarino, I.; Cavalheiro, É.T.G.; Brett, C.M.A. Simultaneous determination of cadmium, lead, copper and mercury ions using organofunctionalized SBA-15 nanostructured silica modified graphite -polyurethane composite electrode. Electroanalysis 2010, 22, 61-68. [CrossRef]

40. Wu, Y.; Yang, T.; Chou, K.C.; Chen, J.; Su, L.; Hou, X. The effective determination of Cd(II) and Pb(II) simultaneously based on an aluminum silicon carbide-reduced graphene oxide nanocomposite electrode. Analyst 2017, 142, 2741-2747. [CrossRef] [PubMed]

41. Lee, P.M.; Chen, Z.; Li, L.; Liu, E. Reduced graphene oxide decorated with tin nanoparticles through electrodeposition for simultaneous determination of trace heavy metals. Electrochim. Acta 2015, 174, $207-214$. [CrossRef] 
42. Sang, S.; Li, D.; Zhang, H.; Sun, Y.; Jian, A.; Zhang, Q.; Zhang, W. Facile synthesis of AgNPs on reduced graphene oxide for highly sensitive simultaneous detection of heavy metal ions. RSC Adv. 2017, 7, 21618-21624. [CrossRef]

43. Liu, G.; Chen, J.; Hou, X.; Huang, W. A highly-sensitive electrochemical sensor for the simultaneous detection of $\mathrm{Cd} 2+$ and $\mathrm{Pb} 2+$ using liquid phase-exfoliated graphene. Anal. Methods 2014, 6, 5760-5765. [CrossRef]

44. Wickremasinghe, R.L. Tea. In Advances in Food Research; Academic Press: Cambridge, MA, USA, 1978; pp. 229-286.

45. Bansod, B.K.; Kumar, T.; Thakur, R.; Rana, S.; Singh, I. A review on various electrochemical techniques for heavy metal ions detection with different sensing platforms. Biosens. Bioelectron. 2017, 94, 443-455. [CrossRef]

(C) 2020 by the authors. Licensee MDPI, Basel, Switzerland. This article is an open access article distributed under the terms and conditions of the Creative Commons Attribution (CC BY) license (http://creativecommons.org/licenses/by/4.0/). 